\title{
Prevalence of Hypertension and Associated
}

\section{Factors Among Adults in Debre Berhan Town, North Shoa Zone, Ethiopia, 2020}

\author{
Demelash Geset Haile' \\ Nigussie Taddess Sharew (D) ${ }^{2}$ \\ Abinet Dagnaw Mekuria (iD ${ }^{3}$ \\ Ayele Mamo Abebe (iD ${ }^{2}$ \\ Yordanos Mezemir (D) \\ 'Debre Berhan Health Science College, \\ Department of Nursing, Debre Berhan, \\ Ethiopia; ${ }^{2}$ Debre Berhan University \\ Health Science College, Department of \\ Nursing, Debre Berhan, Ethiopia; ${ }^{3}$ Debre \\ Berhan University Health Science \\ Colleges, Department of Public Health, \\ Debre Berhan, Ethiopia
}

Correspondence: Abinet Dagnaw Mekuria

Tel +25। 9134I6934

Email abinetdagn@gmail.com
Introduction: Hypertension is a serious medical condition that significantly increases the risks of heart, brain, kidney, and other diseases. The prevalence is highest in Africa (27\%) and lowest in America (18\%). Hypertension is a major reason for premature death worldwide; this is why it will become a targeted non-communicable disease by 2025 .

Objective: To assess the prevalence of hypertension and associated factors among adults in Debre Berhan town, Amhara region, Ethiopia.

Methods: A community-based cross-sectional study was conducted among 680 participants who were selected by a systematic sampling technique. Data were checked, cleaned, and entered into Epi-data then exported to SPSS-23 for analysis. Hosmer-Lemeshow test was used to check the model fitness. Binary logistic regression analysis was used to see the association between dependent and independent variables. All variables with $\mathrm{p}<0.25$ were taken into the multivariable model to minimize the possible confounders. The multi collinearity test was carried out to see the correlation between independent variables by using a variance inflation factor (VIF). The odds ratio along with $95 \% \mathrm{CI}$ were estimated to measure the strength of association and to identify factors associated with hypertension using multivariable logistic regression. Descriptive statistics in the form of tables, figures, percent with measure of central tendency and dispersion with multivariable analysis were used to report the findings and to identify the factors associated with the outcome variable at a $\mathrm{p}<0.05$.

Results: Among 680 participants, the prevalence of hypertension was $27.5 \%$. Sex, being male (AOR: 1.77, 95\% CI: 1.12-2.81), alcohol consumption (AOR: 2.76: 95\% CI: $1.87-$ 4.05), physical exercise (AOR: 2.17, 95\% CI: 1.28-3.71), being overweight (AOR: 1.99, 95\% CI: 1.11-3.58), and family history of hypertension (AOR: $2.10,95 \% \mathrm{CI}: 1.43-3.08$ ) were found to be significantly associated with hypertension.

Conclusion and Recommendation: Prevalence of hypertension in Debre Berhan town was relatively high compared with other studies. So, it is necessary to emphasize intervention in the community for behavioral change, in order to minimize alcohol consumption and to encourage adoption of regular physical exercise, with the existing health system and partners working on hypertension.

Keywords: hypertension, prevalence, adult, Debre Berhan

\section{Background}

Hypertension is defined as systolic blood pressure greater than or equal to 140 $\mathrm{mmHg}$ and diastolic blood pressure $90 \mathrm{mmHg}$ and above. ${ }^{1}$ It is a "silent killer" due to no warning signs or symptoms, and many people do not know whether they have it or not. ${ }^{2}$ 
The growth of urbanization is one of the main reasons for the increasing prevalence of hypertension in Africa. The levels of hypertension are higher in urban than in rural settings mainly because of behavioral factors associated with urban settings such as dietary changes and sedentary lifestyles. ${ }^{3,4}$

The predisposing factors of hypertension are age, sex, marital status, unhealthy diet, physical activity, obesity, too much alcohol, smoking, and also hereditary factors. ${ }^{5,6}$ Hypertension is a primary cause of financial problems, including the cost of caring for all the complications arising from it such as stroke, congestive heart failure., Hypertension is a major problem in the world, causing around 10.4 million deaths per year and mostly the suffering groups are in low and middle-income countries. ${ }^{8,9}$

Hypertension is one of the main risk factors for cardiovascular disease-associated deaths in Ethiopia, and it affects $15.9 \%$ of the population; an Ethiopian noncommunicable diseases report shows that nationally $16 \%$ of the population were affected..$^{10}$ In Debre Berhan town, from a health institution report, there were 6074 hypertension cases. Hypertension also has a wide distribution in the Amhara region, North Shoa zone in which there are 26,071 cases of hypertension and it accounts for $56 \%$ of all the non-communicable diseases. ${ }^{11}$ Currently the Federal Ministry of Health and a few organizations are participating in hypertension prevention and control programs, although they started late and do not address all the Ethiopian population. ${ }^{12}$

\section{Methods and Materials Study Setting}

The study was conducted in Debre Berhan town, North Shoa zone, and Amhara regional state. It is located in the eastern part of the Amhara region, $130 \mathrm{~km}$ to the north of Addis Ababa. Based on 2019 demographic data, the town has a total population of 114,652 (Female $=62,809$ and Male $=51,843) .{ }^{13}$ The town has one public referral hospital, one private general hospital, three health centers, nine health posts, and three private clinics which provide different health services for the community and people coming from different neighboring regions.

\section{Study Design}

Community based cross-sectional study design was conducted among 680 study participants in Debre Berhan town from February 9, 2020-March 8, 2020. The town is located $130 \mathrm{~km}$ to the north of Addis Ababa.

\section{Sample Size Determination}

The sample size was determined by using a single population proportion formula and with an assumption of $95 \%$ confidence level, 5\% marginal error, and a proportion of $27.9 \% .{ }^{14}$ Finally, a total of 680 sample size was calculated, considering a design effect of 2 and $10 \%$ non-response rate.

\section{Sampling Technique}

Using the sampling frame of all 9 kebeles of Debre Berhan town, 4 kebeles were selected by using a simple random sampling technique. The required sample size was taken proportional to the size of the sample frame selected kebele. To get the individual sample units in each household level, systematic random sampling was conducted by using the total household adult and number of samples required in each kebele. After getting the sampling fraction in the selected kebele a lottery method was used to get the first "k" units of the households which is 13. For those households greater than one subject, the lottery method was used to select study participants.

\section{Data Collection Tools and Procedures}

Data collection instruments were questionnaires, BP apparatus, and measuring of anthropometry. The questionnaire was adapted from the WHO STEP wise approach recommended for non-communicable disease surveillance. ${ }^{15}$ The questionnaire was prepared in English language and then translated into the local language (Amharic) by experts to check for consistency.

Blood pressure was measured using an aneroid sphygmomanometer with a stethoscope after respondents waited for at least 5 minutes. Participants were asked for alcohol consumed, smoking, and taking caffeine after having a rest for 30 minutes before measurement. Two consecutive blood pressure measurements were taken 5 minutes apart for all study respondents in a sitting position with the appropriate cuff size that covers $2 / 3$ of the upper arm. Finally, by taking an average of the two BP measurements, the status of the participant was determined. Weight was measured with a Seca-213 portable stadiometer. Participants are asked to remove any heavy outer garments such as jacket, coat, and shoes. The weights are moved until the beam balances (the arrows are aligned). Finally, the weight is recorded to the resolution of the scale (the nearest $100 \mathrm{~g}$ ).

The participant is asked to stand with his/her back to the height rule. The back of the head, back, buttocks, and heels should be touching the stadiometer, feet together. The 
headpiece of the stadiometer or the sliding part of the measuring rod is lowered so that the hair is pressed flat. Height is recorded to the nearest centimeter. Measuring waist circumference, the approximate midpoint between the lower margin of the last palpable ribs and the top of the iliac crest was taken. Hip circumference should be measured as the maximal circumferences over the buttocks. Both hip and waist circumference are measured by non-elastic tape meter. Finally, waist to hip ratio (WHR) was the result of waist circumference divided by hip circumference. All measurements were taken early from 7 am to $9 \mathrm{am}$, and from $3 \mathrm{pm}$ to $12 \mathrm{pm}$ in a convenient place.

\section{Data Quality Management}

Before starting the actual data collection, 1-day training was given for data collectors. The questionnaire was pretested with $5 \%$ of the study sample. The instruments for the BP apparatus were calibrated before the actual procedure was performed. Continuous supervision was done in the spot area by the recruited supervisor to check the completeness of data and monitor the whole data collection process.

\section{Data Processing and Analysis}

The collected data were repeatedly checked for completeness and cleaned, then entered into Epi-Data version 3.1 and then exported to SPSS version 23 for analysis. Hosmer-Lemeshow test was used to check the model fitness. Binary logistic regression analysis was used to see the association between dependent and independent variables. All variables with a $p$-value $<0.25$ were taken into the multivariable model to minimize the possible confounders. The multi collinearity test was carried out to see the correlation between independent variables by using a variance inflation factor (VIF). The odds ratio along with $95 \%$ CI were estimated to measure the strength of association and to identify factors associated with hypertension using multivariable logistic regression. Based on multivariable logistic regression all variables with a p-value less than 0.05 on bivariate results were taken as a significant determinant of hypertension. Finally, the findings of the study were presented by the text, graphs, and table.

\section{Result}

\section{Socio-Demographic Characteristics of the Participants}

In this study, a total of 680 respondents were included with a $100 \%$ response rate, of which $351(51.6 \%)$ were female participants. The mean age of respondents was $36.4 \pm 9.1$
SD, and $387(56.9 \%)$ and $540(79.4 \%)$ respondents were married and Orthodox followers, respectively (Table 1).

\section{Behavioral Factors of Hypertension}

In behavioral factors; 90 (13.2\%) of participants were cigarette smokers, half (48.1\%) of participants were alcohol consumers, $141(20.7 \%)$ of participants took regular physical exercise and $596(87.6 \%)$ of participants reported that they consumed fruit three or more days per week (Table 2).

\section{Health-Related Factors of Hypertension}

In health-related factors of hypertension, about 89 (13.1\%) of participants were a previously known hypertension

Table I Socio-Demographic Characteristics of Adults in Debre Berhan Town, North Shoa Zone Ethiopia, 2020 ( $n=680$ )

\begin{tabular}{|c|c|c|c|}
\hline Variables & Category & Frequency & Percentage (\%) \\
\hline \multirow[t]{2}{*}{ Sex } & Male & 329 & 48.4 \\
\hline & Female & 351 & 51.6 \\
\hline \multirow[t]{4}{*}{ Age group } & $18-27$ & 98 & 14.4 \\
\hline & $28-37$ & 302 & 44.4 \\
\hline & $38-47$ & 207 & 30.4 \\
\hline & $>48$ & 73 & 10.7 \\
\hline \multirow[t]{3}{*}{ Marital Status } & Married & 387 & 56.9 \\
\hline & Single & 252 & 37.1 \\
\hline & Others $^{\mathrm{a}}$ & $4 I$ & 6.0 \\
\hline \multirow[t]{3}{*}{ Religion } & Orthodox & 540 & 79.4 \\
\hline & Muslim & 74 & 10.9 \\
\hline & Others $^{\mathrm{b}}$ & 66 & 9.7 \\
\hline \multirow[t]{5}{*}{$\begin{array}{l}\text { Educational } \\
\text { status }\end{array}$} & $\begin{array}{l}\text { Ist degree and } \\
\text { above }\end{array}$ & 301 & 44.3 \\
\hline & Diploma & 206 & 30.3 \\
\hline & Grade 9-12 & 92 & 13.5 \\
\hline & Grade I-8 & 43 & 6.3 \\
\hline & Others ${ }^{c}$ & 38 & 5.6 \\
\hline \multirow[t]{4}{*}{$\begin{array}{l}\text { Occupational } \\
\text { status }\end{array}$} & $\begin{array}{l}\text { Gov't } \\
\text { employee }\end{array}$ & 369 & 54.3 \\
\hline & Merchant & 142 & 20.9 \\
\hline & $\begin{array}{l}\text { Private } \\
\text { employee }\end{array}$ & 116 & 17.1 \\
\hline & Others $^{\mathrm{d}}$ & 53 & 7.8 \\
\hline Monthly & $<2000$ & 73 & 10.7 \\
\hline \multirow{4}{*}{ income (ETB) } & $200 I-3000$ & 130 & 19.1 \\
\hline & $300 I-4000$ & 136 & 20.0 \\
\hline & $400 I-5000$ & 147 & 21.6 \\
\hline & $\leq 5000$ & 194 & 28.5 \\
\hline
\end{tabular}

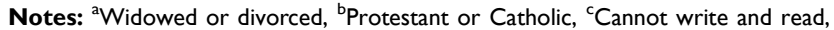
only read and write, Jobless or housewife. 
Table 2 Behavioral Characteristics of Respondents Among Adults in Debre Berhan Town, North Shoa Zone Ethiopia, $2020(n=680)$

\begin{tabular}{|c|c|c|c|}
\hline Variables & Category & Frequency & $\begin{array}{l}\text { Percent } \\
\text { (\%) }\end{array}$ \\
\hline Cigarette smoking & $\begin{array}{l}\text { Yes } \\
\text { No }\end{array}$ & $\begin{array}{l}90 \\
590\end{array}$ & $\begin{array}{l}13.2 \\
86.8\end{array}$ \\
\hline Khat chewing & $\begin{array}{l}\text { Yes } \\
\text { No }\end{array}$ & $\begin{array}{l}125 \\
555\end{array}$ & $\begin{array}{l}18.4 \\
81.6\end{array}$ \\
\hline Alcohol drinking & $\begin{array}{l}\text { Yes } \\
\text { No }\end{array}$ & $\begin{array}{l}327 \\
353\end{array}$ & $\begin{array}{l}48.1 \\
51.9\end{array}$ \\
\hline $\begin{array}{l}\text { Frequency of alcohol } \\
\text { drinking }\end{array}$ & $\begin{array}{l}\text { Daily } \\
\text { Weekly } \\
\text { Sometimes }\end{array}$ & $\begin{array}{l}48 \\
59 \\
220\end{array}$ & $\begin{array}{l}14.7 \\
18.0 \\
67.3\end{array}$ \\
\hline Doing physical activity & $\begin{array}{l}\text { Yes } \\
\text { No }\end{array}$ & $\begin{array}{l}141 \\
539\end{array}$ & $\begin{array}{l}20.7 \\
79.3\end{array}$ \\
\hline Frequency of exercise & $\begin{array}{l}\text { Low } \\
\text { Moderate } \\
\text { Highest }\end{array}$ & $\begin{array}{l}54 \\
50 \\
37\end{array}$ & $\begin{array}{l}38.3 \\
35.5 \\
26.2\end{array}$ \\
\hline Fruit consumption & $\begin{array}{l}\text { Never use } \\
\text { I-2 days/week } \\
3 \text { or more days/ } \\
\text { week }\end{array}$ & $\begin{array}{l}36 \\
48 \\
596\end{array}$ & $\begin{array}{l}5.3 \\
7.1 \\
87.6\end{array}$ \\
\hline $\begin{array}{l}\text { Vegetable } \\
\text { consumption }\end{array}$ & $\begin{array}{l}\text { Never use } \\
\text { I-2 days/week } \\
3 \text { or more days/ } \\
\text { week }\end{array}$ & $\begin{array}{l}42 \\
57 \\
581\end{array}$ & $\begin{array}{l}6.2 \\
8.4 \\
85.4\end{array}$ \\
\hline
\end{tabular}

patient, whereas 309 (45.4\%) of respondents had a family history of hypertension. Regarding body mass index (BMI), 116 (17.1\%) respondents were overweight, while $33(10 \%)$ of males and 131 (37.3\%) of female participants were obese (Table 3 ).

\section{Prevalence and Associated Factors of Hypertension}

Prevalence of Hypertension

The prevalence of hypertension in this study was found to be $187(27.5 \%)$. The mean SBP and DBP results were $124.6 \mathrm{mmHg} \pm 12.1 \mathrm{SD}$ and $78.8 \mathrm{mmHg} \pm 9.3 \mathrm{SD}$ respectively. Among all hypertensive people identified, 98 $(14.4 \%)$ did not know they were hypertensive (new cases); 89 (13.1\%) hypertensive participants reported that they were using anti-hypertensive drugs during the data collection period, and $62(69.7 \%)$ had normal blood pressure on measurement (Figure 1).
Table 3 Health-Related Characteristics of Respondents Among Adults in Debre Berhan Town, North Shoa Zone Ethiopia, 2020 $(n=680)$

\begin{tabular}{|c|c|c|c|c|}
\hline Variables & & Category & Frequency & $\begin{array}{l}\text { Percent } \\
\text { (\%) }\end{array}$ \\
\hline $\begin{array}{l}\text { Known HTN } \\
\text { patient }\end{array}$ & & $\begin{array}{l}\text { Yes } \\
\text { No }\end{array}$ & $\begin{array}{l}89 \\
591\end{array}$ & $\begin{array}{l}13.1 \\
86.9\end{array}$ \\
\hline $\begin{array}{l}\text { Family history } \\
\text { of HTN }\end{array}$ & & $\begin{array}{l}\text { Yes } \\
\text { No }\end{array}$ & $\begin{array}{l}309 \\
371\end{array}$ & $\begin{array}{l}45.4 \\
54.6\end{array}$ \\
\hline History of DM & & $\begin{array}{l}\text { Yes } \\
\text { No }\end{array}$ & $\begin{array}{l}279 \\
401\end{array}$ & $\begin{array}{l}41.0 \\
59.0\end{array}$ \\
\hline BMI $\left(\mathrm{kg} / \mathrm{m}^{2}\right)$ & & $\begin{array}{l}\text { Underweight } \\
\text { Normal } \\
\text { Overweight } \\
\text { Obese }\end{array}$ & $\begin{array}{l}19 \\
540 \\
116 \\
5\end{array}$ & $\begin{array}{l}2.8 \\
79.4 \\
17.1 \\
0.7\end{array}$ \\
\hline \multirow[t]{2}{*}{ BFP (\%) } & Male & $\begin{array}{l}\text { Normal } \\
\text { Obese }\end{array}$ & $\begin{array}{l}296 \\
33\end{array}$ & $\begin{array}{l}90.0 \\
10.0\end{array}$ \\
\hline & Female & $\begin{array}{l}\text { Normal } \\
\text { Obese }\end{array}$ & $\begin{array}{l}220 \\
131\end{array}$ & $\begin{array}{l}62.7 \\
37.3\end{array}$ \\
\hline \multirow[t]{2}{*}{ WHR (\%) } & Male & $\begin{array}{l}\text { Normal } \\
\text { Risk }\end{array}$ & $\begin{array}{l}28 \\
301\end{array}$ & $\begin{array}{l}8.5 \\
91.5\end{array}$ \\
\hline & Female & $\begin{array}{l}\text { Normal } \\
\text { Risk }\end{array}$ & $\begin{array}{l}17 \\
334\end{array}$ & $\begin{array}{l}4.8 \\
95.2\end{array}$ \\
\hline
\end{tabular}

Abbreviations: BMI, body mass index; BFP, body fat percentage; DM, diabetes mellitus; HTN, hypertension; WHR, waist to hip ratio.

\section{Associated Factors of Hypertension:}

\section{A Multivariable Analysis}

On the multivariable logistic analysis being male, family history of hypertension, alcohol consumption, physical inactivity, and being overweight were significantly associated with hypertension $(\mathrm{p}<0.05)$. However, the age of respondents, marital status, khat chewing, body fat percentage (BFP), and cigarette smoking did not have a significant association with hypertension in the Bivariate analysis, but the variables were not statistically significant on multivariable logistic regression (Table 4).

\section{Discussion}

The prevalence of hypertension at the community level was $27.5 \%$. This finding is higher than the findings of previous studies conducted in Tigray (16\%), Bedele (16.9\%), Bahir Dar (11.4\%), Debre Markos (12.5\%), Coastal Karnataka India (16.72\%), Tanzania (8\%), and North India (14.4\%). ${ }^{16-22}$ This difference might be due to the difference in sample size, behavioral factors like 


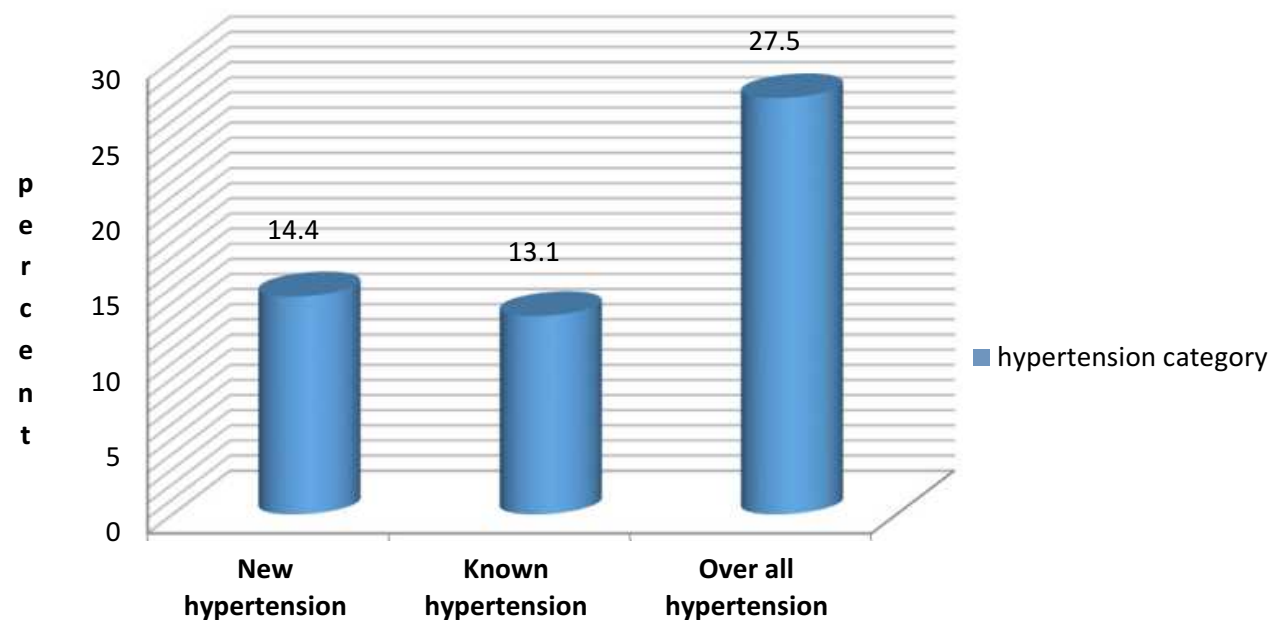

Figure I Prevalence of hypertension among adults in Debre Berhan town, North Shoa zone, Ethiopia; 2020.

smoking with advanced possibility of difference in educational status, exercise, and cultural differences. The discrepancy may also be due to the difference in age group in the previous and current studies. The previous studies included a high number of younger participants $\left(33.9 \%,{ }^{21} 38.9 \%,{ }^{16} 27.2 \%{ }^{20}\right)$ but the current study has $14.4 \%$ of young participants. The other reason may be the residence of participants engaged in the study. In the current study, all participants were from urban areas, whereas the previous studies included both rural and urban areas.

The prevalence of hypertension was lower than studies done in Iraq, ${ }^{23}$ Varanasi, ${ }^{24}$ and in the Middle East and North Africa, ${ }^{25}$ in which the reported prevalences were $54.7 \%, 32.9 \%$, and $32.3 \%$, respectively. This discrepancy might be due to the difference in the socio-economic status of participants between the study populations. This study prevalence was in line with the study conducted in Gondar (27.9\%), in which the similarity might be due to the contextual similarity of socio-demographic character, and study design.

Regarding the predictors of hypertension, sex, alcohol consumption, regular physical exercise, BMI, and family history of hypertension were significantly associated with hypertension.

Sex is one of the determinants for hypertension identified in this study, as males had odds almost two times higher when compared with females to develop likelihood of hypertension. This study was supported by studies conducted in Jigiiga, ${ }^{26}$ Hosanna, ${ }^{27}$ and India. ${ }^{28}$ The possible explanation for this finding might be due to that males are more exposed to risky behavior such as khat chewing, since khat increases catecholamine release which results in vasoconstriction, ${ }^{13,29}$ and alcohol taking, since a high intake of alcohol stimulates the release of endothelin 1 and 2 as well as angiotensin II which are known to be potent vasoconstrictors. ${ }^{30,31}$

But this finding disagrees with a study conducted in Tanzania ${ }^{16}$ in which the finding shows that females were more exposed to hypertension than males. It may be due to difference in the study participants as the majority of the participants were female $(65 \%)$ or it may be due to body fat accumulation being higher in the participating females than males.

Another determinant of hypertension in this study was alcohol consumption. The odds of developing hypertension among alcohol consumers were almost three times higher compared with those who did not consume alcohol. This result was supported by studies carried out in Gondar, ${ }^{32}$ Kenya ${ }^{33}$ India, ${ }^{28}$ and Nepal. ${ }^{34}$ This might be due to similarity in residence and exposure to risk factors like harmful use of alcohol and time to time increment of alcohol consumers.

Regular physical exercise was another predictor to develop hypertension. The study participants who did not perform regular physical exercise were two times more likely to develop hypertension. The current study was supported by studies conducted in North India, ${ }^{21}$ Addis Ababa ${ }^{35}$ and Hosanna, Ethiopia. ${ }^{27}$ It might be due to high accumulation of fat in the tissue and organs to alter hemodynamic pathways and it leads to the development of hypertension for those who did not practice regular exercise.

The study participants who had a family history of hypertension were two times more likely to develop 
Table 4 Bivariable and Multivariable Analysis of Factors Associated with Hypertension Among Adult Participants in Debre Berhan Town, North Shoa Zone, Ethiopia, 2020

\begin{tabular}{|c|c|c|c|c|c|}
\hline \multicolumn{2}{|l|}{ Variable Category } & \multicolumn{2}{|c|}{ Hypertension (\%) } & \multirow{3}{*}{$\begin{array}{l}\text { COR }(95 \% \mathrm{CI}) \\
1.96(1.39-2.76) \\
\end{array}$} & \multirow{3}{*}{$\begin{array}{l}\text { AOR }(95 \% \mathrm{Cl}) \\
\mathrm{I} .77(1.12-2.8 \mathrm{I}) * \\
\mathrm{I}\end{array}$} \\
\hline & & \multirow{2}{*}{$\begin{array}{l}\text { Yes } \\
113(34.3) \\
74(21.1)\end{array}$} & \multirow{2}{*}{$\begin{array}{l}\text { No } \\
216(65.7) \\
277(78.9)\end{array}$} & & \\
\hline Sex & $\begin{array}{l}\text { Male } \\
\text { Female }\end{array}$ & & & & \\
\hline Age group & $\begin{array}{l}18-27 \\
28-37 \\
38-47 \\
>48\end{array}$ & $\begin{array}{l}18(18.4) \\
64(21.2) \\
73(35.3) \\
32(43.8)\end{array}$ & $\begin{array}{l}80(81.6) \\
238(78.8) \\
134(64.7) \\
41(56.2)\end{array}$ & $\begin{array}{l}\text { I } \\
1.19(0.67-2.14) \\
2.42(1.35-4.35) \\
3.47(1.74-6.91)\end{array}$ & $\begin{array}{l}0.99(0.52-1.88) \\
1.44(0.72-2.99) \\
I .61(0.68-3.84)\end{array}$ \\
\hline Marital status & $\begin{array}{l}\text { Married } \\
\text { Single } \\
\text { Others }^{\mathrm{a}}\end{array}$ & $\begin{array}{l}124(32.0) \\
53(21.0) \\
10(24.4)\end{array}$ & $\begin{array}{l}263(68.0) \\
199(79.0) \\
31(75.6)\end{array}$ & $\begin{array}{l}\text { I } \\
0.57(0.39-0.82) \\
0.68(0.33-1.44)\end{array}$ & $\begin{array}{l}0.69(0.45-1.07) \\
0.70(0.31-1.55)\end{array}$ \\
\hline Khat chewing & $\begin{array}{l}\text { Yes } \\
\text { No }\end{array}$ & $\begin{array}{l}51(40.8) \\
136(24.5)\end{array}$ & $\begin{array}{l}74(59.2) \\
419(75.5)\end{array}$ & $\begin{array}{l}2.12(1.42-3.19) \\
1\end{array}$ & $1.49(0.92-2.40)$ \\
\hline Alcohol drinking & $\begin{array}{l}\text { Yes } \\
\text { No }\end{array}$ & $\begin{array}{l}123(37.6) \\
64(18.1)\end{array}$ & $\begin{array}{l}204(62.4) \\
289(81.9)\end{array}$ & $\begin{array}{l}2.72(1.92-3.87) \\
I\end{array}$ & $\begin{array}{l}2.76(1.87-4.05)^{* *} \\
1\end{array}$ \\
\hline Family history of hypertension & $\begin{array}{l}\text { Yes } \\
\text { No }\end{array}$ & $\begin{array}{l}103(33.3) \\
84(22.6)\end{array}$ & $\begin{array}{l}206(66.7) \\
287(77.4)\end{array}$ & $\begin{array}{l}1.71(1.22-2.39) \\
\mathrm{I}\end{array}$ & $\begin{array}{l}2.10(1.43-3.08)^{* *} \\
\mathrm{I}\end{array}$ \\
\hline Smoking & $\begin{array}{l}\text { Yes } \\
\text { No }\end{array}$ & $\begin{array}{l}37(4 \mid .1) \\
150(25.4)\end{array}$ & $\begin{array}{l}53(58.9) \\
440(74.6)\end{array}$ & $\begin{array}{l}2.05(1.29-3.24) \\
1\end{array}$ & $1.34(0.80-2.31)$ \\
\hline Doing regular physical activity & $\begin{array}{l}\text { Yes } \\
\text { No }\end{array}$ & $\begin{array}{l}21(14.9) \\
166(30.8)\end{array}$ & $\begin{array}{l}120(85.1) \\
373(69.2)\end{array}$ & $\begin{array}{l}\text { I } \\
2.54(1.55-4.19)\end{array}$ & $\begin{array}{l}\text { I } \\
2.17(\mid .28-3.7 I)^{*}\end{array}$ \\
\hline BMI $\left(\mathrm{kg} / \mathrm{m}^{2}\right)$ & $\begin{array}{l}\text { Normal } \\
\text { Overweight } \\
\text { Obese } \\
\text { Under weight }\end{array}$ & $\begin{array}{l}I 35(24.7) \\
50(45.9) \\
I(20.0) \\
I(5.3)\end{array}$ & $\begin{array}{l}412(75.3) \\
59(54.1) \\
4(80.0) \\
18(94.7)\end{array}$ & $\begin{array}{l}\text { I } \\
2.58(1.64-3.77) \\
0.76(0.09-6.90) \\
0.17(0.02-1.29)\end{array}$ & $\begin{array}{l}\text { I } \\
1.99(I .11-3.58)^{*} \\
0.62(0.06-6.25) \\
0.16(0.02-1.24)\end{array}$ \\
\hline BFP & $\begin{array}{l}\text { Normal } \\
\text { Obese }\end{array}$ & $\begin{array}{l}125(24.2) \\
62(37.8)\end{array}$ & $\begin{array}{l}391(75.8) \\
102(62.2)\end{array}$ & $\begin{array}{l}\text { I } \\
1.90(1.31-2.77)\end{array}$ & $\mathrm{I} .34(0.7 \mathrm{I}-2.5 \mathrm{I})$ \\
\hline
\end{tabular}

Notes: I: reference, *Significantly associated with $\mathrm{p}<0.00 \mathrm{I}$ on multiple logistic regression. ${ }^{* *}$ Significantly associated with $\mathrm{p}<0.05$ on multiple logistic regression, ${ }^{\mathrm{a}}$ Widowed or divorced.

Abbreviations: AOR, adjusted odds ratio; $\mathrm{BFP}$, body fat percentage; $\mathrm{Cl}$, confidence interval; COR, crude odds ratio.

hypertension than their counterparts. This was supported by studies conducted in Durame, ${ }^{36}$ coastal Karnataka India, $^{22}$ and south India. ${ }^{28}$ The possible explanation for this may be that the family tends to share the same genes that can predispose the person to high blood pressure and stroke. Moreover, this may be because relatives shared similar activities such as food choices, exercise, and alcohol drinking that can affect health.

This study shows an increment in BMI was identified as a risk factor for hypertension. The study participants who were overweight were two times more likely to develop hypertension than their counterparts. This study was supported by other research findings in Debre Markos and South-eastern Nepal. ${ }^{20,37}$ This may be due to the difference in feeding habits, and lack of exercise.

\section{Conclusion and Recommendation}

This study shows that the prevalence of hypertension among adult groups was relatively higher compared with other studies. Sex, alcohol consumption, regular physical exercise, body mass index, and family history of hypertension had a significant association with hypertension. Enhanced health education for the community is needed in order to reduce alcohol consumption and adopt regular physical exercise. Strengthening and expanding community services that focus on non-communicable disease control like hypertension is needed. It will be necessary 
to arrange programs for regular physical exercise and to conduct further studies like cohort study and case-control to assess additional factors.

\section{Declaration of Helsinki}

We declare that the research is governed by the Declaration of Helsinki.

\section{Limitation of the Study}

Inability to perform biochemical tests, due to infrastructural and economic limitations.

\section{Data Sharing Statement}

All data are accessed in this manuscript.

\section{Ethical Approval and Consent to Participant}

Ethical clearance was obtained from Debre Berhan University, health science college research committee. And also a supportive letter was obtained from Debre Berhan Town Wereda health office to all selected kebeles administrative offices. Each study participant was adequately informed about the purpose, method, and anticipated benefit and risk of the study by their data collector. Respondents had the right to respond or refuse the interview. Written consent was received from study participants. All the information given by respondents was used for research purposes only and confidentiality and privacy were kept by omitting the name of the respondents during the data collection procedure.

\section{Consent for Publication}

Not applicable.

\section{Acknowledgment}

The authors would like to thank Debre Berhan University, Debre Berhan Health Science College and, Debre Berhan town Health Bureau for providing sponsorship. All study participants are thanked for their cooperation during sample collection.

\section{Author Contributions}

All authors contributed to data analysis, drafting and, revising the article, have agreed on the journal to which the article will be submitted, gave final approval of the version to be published and, agreed to be accountable for all aspects of the work.

\section{Funding}

There is no funding to report.

\section{Disclosure}

The authors declare that they have no conflicts of interest for this work.

\section{References}

1. World Health Organization. A Global Brief On Hypertension Silent Killer, Global Public Health Crisis. 20 Avenue Appia, 1211 Geneva 27, Switzerland: 2013 Contract No.: who/Dco/Whd/2013.2.

2. Sawicka K, Szczyrek M, Jastrzebska I, Prasal M, Zwolak A, Daniluk J. Hypertension-The Silent Killer. J Pre-Clin Clin Res. 2011;5(2).

3. African U. The impact of Non-Communicable Diseases (NCDs) And Neglected Tropical Diseases (Ntds) On Development In Africa; 2013.

4. Kibret K, Mesfin Y. Prevalence of hypertension in ethiopia: a systematic meta-analysis. Public Health Rev. 2015;36(1):14. doi:10.1186/s40985-015-0014-z

5. Van De Vijver S, Akinyi H, Oti S, Kyobutungi C, editors. The impact of Non-Communicable Diseases (NCDs) and Neglected Tropical Diseases (Ntds) on development in Africa. au conference of ministers of health (Camh6) sixth ordinary session; 2013.

6. Felman A. Everything you need to know about hypertension. Medical News Today; 2019. Available from: https://www.medicalnewstoday. com/articles/150109.

7. Federal Democratic Republic Of Ethiopia Ministry Of Health. The ethiopia noncommunicable diseases and injuries (Ncdi) Report Summary; 2018.

8. Bisanzio D, Shokraneh F; Collaborators Grf. Global, regional, and national comparative risk assessment of 84 behavioural, environmental and occupational, and metabolic risks or clusters of risks for 195 countries and territories, 1990-2017: a systematic analysis for the global burden of disease stu; 2018.

9. Mills K, Bundy J, Kelly T, et al. Global disparities of hypertension prevalence and control: a systematic analysis of population-based studies from 90 countries. Circulation. 2016;134(6):441-450. doi:10.1161/CIRCULATIONAHA.115.018912

10. World Health Organization (WHO). Ethiopia sets to improve hypertension prevention and control at primary health care level (Phc). [Internet]; 2019. Available from: Https://Www.Afro.Who.Int/News/ Ethiopia-Sets-Improve-Hypertension-Prevention-And-ControlPrimary-Health-Care-Level. Accessed July 31, 2019.

11. Debre Berhan North Shoa Zone Health Department. Annual hypertension report; July 2018. November.2019.

12. Ethiopian Herald (Addis Ababa). Due attention to hypertension. [Internet]; 2019. Available from: Https://Allafrica.Com/Stories/ 201805310462.Html. Accessed May 2018.

13. El-Menyar A, Mekkodathil A, Al-Thani H, Al-Motarreb A. Khat use: history and heart failure. Oman Med J. 2015;30(2):77-82. doi:10.5001/omj.2015.18

14. Abebe S, Berhane Y, Worku A, Getachew A. Prevalence and associated factors of hypertension: a Crossectional Community Based Study In Northwest Ethiopia. PLoS One. 2015;10(4). doi:10.1371/ journal.pone. 0125210

15. A A. WHO STEPwise approach to chronic disease risk factor surveillance (STEPS). [Internet]; 2011. Available from: http://www.fao. org/fileadmin/templates/agphome/documents/horticulture/WHO/ arusha/WHOSTEPS.pdf. Accessed October 2019.

16. Mosha N, Mahande M, Juma A, et al. Prevalence, awareness, and factors associated with hypertension in North West Tanzania. Glob Health Action. 2017;10(1):1321279. doi:10.1080/16549716.2017.1321279 
17. Bayram A, Meles K, Sibhatu Y. Magnitude and risk factors for hypertension among public servants in Tigray, Ethiopia: a Cross-Sectional Study. PLoS One. 2018;13(10). doi:10.1371/journal.pone.0201652

18. Bonsa F, Gudina E, Hajito K. Prevalence of hypertension and associated factors in Bedele Town, Southwest Ethiopia. Ethiop J Health Sci. 2014;24(1):21-26. doi:10.4314/ejhs.v24i1.3

19. Tesfaye T, Temesgen W, Kasa A, Yismaw Y. Prevalence and associated factors of hypertension in amhara regional state city and its' surrounding rural districts: a Community-Based Cross-Sectional Study. Afr Health Sci. 2019;19(3):2580-2590. doi:10.4314/ahs.v19i3.34

20. Kiber M, Wube M, Temesgen H, Woyraw W, Belay Y. Prevalence of hypertension and its associated factors among adults in Debre Markos Town, Northwest Ethiopia: community Based Cross-Sectional Study. BMC Res Notes. 2019;12(1):406. doi:10.1186/s13104-019-4431-9

21. Ahmad S. Prevalence and risk factors of hypertension, among adults residing in an Urban Area North India; 2015.

22. Veientlena S, Prabu P. Prevalence of hypertension and determination of its risk factors in Korangrapady, Udupi District, Coastal Karnataka, India. Prevalence. 2018;11(6).

23. Saka M, Shabu S, Shabila N. Prevalence of hypertension and associated risk factors in a population sample of older adults in Kurdistan, Iraq. East Mediterr Health J. 2019;25:2.

24. Singh S, Shankar R, Singh G. Prevalence and associated risk factors of hypertension: a Cross-Sectional Study In Urban Varanasi. Int J Hypertens. 2017;2017. doi:10.1155/2017/5491838

25. Sarki A, Nduka C, Stranges S, Kandala N-B, Uthman O. Prevalence of hypertension in low-and middle-income countries: a systematic review and meta-analysis. Medicine. 2015;94(50). doi:10.1097/ MD.0000000000001959

26. Asresahegn H, Tadesse F, Beyene E. Prevalence and associated factors of hypertension among adults in Ethiopia: a Community Based Cross-Sectional Study. BMC Res Notes. 2017;10(1):629. doi:10.1186/s13104-017-2966-1

27. Asfaw L, Ayanto S, Gurmamo F. Hypertension and its associated factors in Hosanna Town, Southern Ethiopia: community Based Cross-Sectional Study. BMC Res Notes. 2018;11(1):306. doi:10.1186/s13104-018-3435-1

28. Paul P, Samson R, William A, Akila B, Purty A, Bazroy J. Prevalence and factors associated with hypertension: a Community Based Cross-Sectional Study Among Adults In An Urban Area Of Puducherry, South India. Int J Commun Med Public Health. 2017;4:1620-1626. doi:10.18203/2394-6040.ijcmph20171774
29. Geta TG, Woldeamanuel GG, Hailemariam BZ, Bedada DT. Association of chronic khat chewing with blood pressure and predictors of hypertension among adults in Gurage Zone, Southern Ethiopia: a Comparative Study. Integr Blood Press Control. 2019;12:33-42. doi:10.2147/IBPC.S234671

30. Fuchs F, Chambless WP, Nieto F, Heiss G. Alcohol consumption and the incidence of hypertension: the atherosclerosis risk in communities study. Hypertension. 2001;37(5):1242-1250. doi:10.1161/01.HYP. 37.5.1242

31. Lemieux AM, Li B, Al'Absi M. Khat use and appetite: an overview and comparison of amphetamine, khat and cathinone. $J$ Ethnopharmacol. 2015;160:78-85. doi:10.1016/j.jep.2014.11. 002

32. Demisse A, Greffie E, Abebe S, et al. High burden of hypertension across the age groups among residents of Gondar City In Ethiopia: a Population-Based Cross-Sectional Study. Bmc Public Health. 2017;17(1):647. doi:10.1186/s12889-017-4646-4

33. Mohamed S, Mutua M, Wamai R, et al. Prevalence, awareness, treatment, and control of hypertension and their determinants: results from A National Survey In Kenya. Bmc Public Health. 2018;18 (3):1-10. doi:10.1186/s12889-018-6052-y

34. Dhungana R, Pandey A, Bista B, Joshi S, Devkota S. Prevalence and associated factors of hypertension: a community-based cross-sectional study in Municipalities Of Kathmandu, Nepal. Int J Hypertens. 2016;2016. doi:10.1155/ 2016/1656938

35. Abebe S, Yallew W. Prevalence of hypertension among adult outpatient clients in hospitals and its associated factors in Addis Ababa, Ethiopia: a Hospital-Based Cross-Sectional Study. BMC Res Notes. 2019;12(1):87. doi:10.1186/s13104-019-4127-1

36. Helelo T, Gelaw Y, Adane A. Prevalence and associated factors of hypertension among adults in Durame Town, Southern Ethiopia. PLoS One. 2014;9(11). doi:10.1371/journal.pone.011 2790

37. Pyakurel P, Yadav DK, Thapa J, et al. Prevalence and associated risk factor of hypertension among individuals of age 18-59 years in South-Eastern Nepal: a Cross-Sectional Study. Nepalese Heart J. 2019;16(1):19-26. doi:10.3126/njh.v16i1.23894
Vascular Health and Risk Management

\section{Publish your work in this journal}

Vascular Health and Risk Management is an international, peerreviewed journal of therapeutics and risk management, focusing on concise rapid reporting of clinical studies on the processes involved in the maintenance of vascular health; the monitoring, prevention and treatment of vascular disease and its sequelae; and the involvement of metabolic disorders, particularly diabetes. This journal is indexed on PubMed Central and MedLine. The manuscript management system is completely online and includes a very quick and fair peerreview system, which is all easy to use. Visit http://www.dovepress. com/testimonials.php to read real quotes from published authors. 